\title{
HETEROTOPIAS IN THE SLOVAK FICTION FILM OF THE 1990s AS SPACES OF SELF-TRANSFORMATION
}

\author{
JANA DUDKOVÁ \\ Institute of Theatre and Film Research, \\ Art Research Centre of the Slovak Academy of Sciences, Bratislava, Slovakia
}

\begin{abstract}
The study examines heterotopias in three distinct Slovak films as symptoms of disenfranchisement on the part of the film-makers during the transformative period in Slovak cinema. The first part analyses idyllic and heterotopic qualities of space in Martin Šulík's Záhrada [The Garden, 1995], while the following parts examine heterotopic spaces in debuts by Štefan Semjan Na krásnom modrom Dunaji [On the Beautiful Blue Danube, 1994] and Miroslav Šindelka Vášnivý bozk [A Passionate Kiss, 1994]. The study shows how heterotopic qualities of spaces in these films correspond with self-transformation of the main characters and how the very processes of self-transformation can serve as commentaries on current situation within Slovak film industry.
\end{abstract}

Keywords: Slovak cinema, postsocialism, heterotopias, space in the film

The present study focuses on the construction of space in selected Slovak films of the first half of the 1990s as both spaces of self-transformation and heterotopias, defined by Foucault as "a kind of effectively enacted utopia in which the real sites, all the other real sites that can be found within the culture, are simultaneously represented, contested, and inverted." ${ }^{11}$ The dramatic economic, political and social transformation of the1990s also influences the construction of spaces in some of the most important films of the period. It is, above all, 'crisis heterotopias' ${ }^{2}$ that we find most productive for our interpretation of the spaces as well as the characters and the sense of isolation or disenfranchisement on the part of the film-makers themselves during this transformative era in Slovak cinema.

At the turn of 1980s and 1990s, the Slovak audio-visual industry underwent fundamental changes. The two crucial events were the privatisation of the Slovak Film Production Bratislava - Kolibaand the transformation of state television into a public one that was launched in late 1989, even before the so-called Velvet Revolution. ${ }^{3}$ Both of these transformations involved massive cuts of creative staff, compounded

${ }^{1}$ FOUCAULT, M. Of Other Spaces: Utopias and Heterotopias. Available at: http://web.mit.edu/allanmc/ www/foucault1.pdf, pp. 3 - 4. This text, entitled "Des Espace Autres," and published by the French journal Architecture, mouvement, continuité in October, 1984, was the basis of a lecture given by Michel Foucault in March 1967. Although not reviewed for publication by the author and thus not part of the official corpus of his work, the manuscript was released into the public domain for an exhibition in Berlin shortly before Michel Foucault's death. Translated from the French by Jay Miskowiec.

${ }^{2}$ Ibid., p. 4.

${ }^{3}$ Transformation of state-run television in Slovakia was initiated by the Union of Socialist Youth during the early autumn of 1989, almost two months before the so called "Velvet Revolution". MISTRÍKOVÁ, Z. ZMEČEK, A. (eds.). Mediálna ročenka - Slovensko 1990 - 2000. Bratislava : Mediálny inštitút, 2001, p. 10. 
by a lack of transparency and alleged unauthorised appropriation of assets. ${ }^{4}$ Yet another fundamental fact hindering the transformation of the industry was a kind of legal trap or legal ambiguity as newly-established private production companies were forced to operate within the legal framework of the Presidential Decree on the Nationalisation of Film Industry (1945) all the way until the end of 1995, ${ }^{5}$ when this decree was abolished or rather substituted by a new Audio-visual Act, enacted by the Slovak Parliament on 1 January, 1996.

The "shifting sands" in both the production base and the creative community resulted at this time not only in a decreasing number of films produced - namely, feature films for theatre release - but also in a growing sentiment of isolation and in a growing segregation of various circles and opinion groups amongst film professionals. This transformation of the social fabric and communities also led to transformation of characters, identities, and spaces which came to be defined by the same existentialist sense of isolation. The films of the 1990s debutants provide a particularly fruitful terrain for tracing these changes as they consciously offer new concepts of both cinematic space and cinema as a space of experience.

\section{The Garden as a Refuge}

Martin Šulík's Záhrada [The Garden, 1995] is one of the Slovak films of the 1990s that relates indirectly to these economic, political, and institutional developments. Slovak film historians agree on the whole that it was the year 1991 that marked the "factual, economic, institutional, as well as creative 'liberation' of the Slovak film

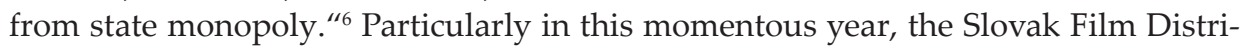
bution Company (Slovenská požičovňa filmov) was privatised. Moreover, a political decision was made enabling privatisation of the Slovak Film Production Bratislava - Koliba (Slovenská filmová tvorba Bratislava - Koliba) preceded by the dismissal of 50 percent of its creative staff, and state subsidy cuts of unprecedented scale for a state enterprise. That same year gave rise to first private film companies, as well as the first film produced by a private company (although with state aid), Rošáda ([Castling] 1991, dir. Peter Patzak). ${ }^{7}$ Moreover, Act No. 95/1991 Coll. paved the way for the establishment of the State Fund for Culture Pro Slovakia that turned out to be the only source of state funding for film production for a number of years to come, until it was replaced by the grant program AudioVízia created in 2004 by the Ministry of Culture. ${ }^{8}$

The rapid decline of Slovak film industry following 1991, caused primarily by the non-transparent and lingering privatisation of the Slovak Film Production Bratislava - Koliba, the shortage of state aid, and the dependence on political factors as well

${ }^{4}$ The moment of possible misappropriation is suggested by film historian Václav Macek in a rare study on this topic (MACEK, V. 1297254000 Sk. In Kino-Ikon, 2010, Vol. 14, Issue 1, pp. 125 - 154), but also by Zuzana Piussi in her film Koliba (2009).

${ }^{5}$ ŠMATLÁK, M. Hladanie vlastnej cesty. In Kino-Ikon, 2008, Vol. 12, Issue 1, p. 138.

${ }^{6}$ Ibid., p. 136.

${ }^{7}$ As a matter of fact, the film was a co-production of two private production companies from Slovakia (StudioTri and IN FILM) and Austrian company Fernsehfilmproduktion Dr. Heinz Scheiderbauer Gesellschaft, Slovak Television Bratislava and Austrian Broacasting Corporation - ORF.

8 ŠMATLÁK, M. Hladanie vlastnej cesty, pp. 136 - 138. 
as the legal vacuum resulted in an ever-decreasing number of film releases. Within a few years, only $2-4$ feature films were being produced annually (including international co-productions, mostly with the Czech Republic) - a condition which lasted until the end of the decade.

Interestingly enough, it is exactly the same year of 1991 that also saw the film debut of Martin Šulík, the only director debuting in the first half of the 1990s who managed to continue creating films without any major break and thus to become one of the most important film auteurs of the decade.

Záhrada [The Garden], the third of Šulík's films, can be understood as a vitally emblematic embodiment of the sense of isolation that the Slovak film community suffered under the rule of Prime Minister Vladimír Mečiar. His administration was not only hostile to many of them, but was also perceived as a key stakeholder in the privatisation of the state film enterprise. In Šulík's Záhrada [The Garden], a long-neglected estate, overgrown by vegetation, sits isolated amidst the vast desert of fields belonging to a farming co-operative. The garden eventually turns into a refuge which can be understood as a heterotopia - one of crisis, above all. According to Foucault's "there is a certain form of heterotopia that I would call crisis heterotopias, i.e., there are privileged or sacred or forbidden places, reserved for individuals who are, in relation to society and to the human environment in which they live, in a state of crisis: adolescents, menstruating women, pregnant women, the elderly, etc." ${ }^{9}$ With regard to the imminent breakup "the heterotopia begins to function at full capacity when men arrive at a sort of absolute break with their traditional time. ${ }^{\prime 10}$ Crisis heterotopias thus come to resemble Mircea Eliade's spaces of initiation that is self-transformation.

It is here, in his private haven, that the film's main character, Jakub, seeks not only to escape from the vices of his unsatisfying life in the capital, but also to revive and revitalise connection with the generation of his forefathers. At the beginning of the film, Jakub appears calm, but grows ever more dissatisfied and ambivalent with regard to his father, an established tailor, who regularly hosts his established clients. One of these is Tereza, a woman some years older than Jakub and socially superior to him, who quickly turns out to be his mistress. The opportunist behaviour of Jakub's father, as well as his dominating, demanding, and all too self-confident lover, gradually deepen Jakub's discontent with his urban life, and prompt him to seek his own individual identity and his autonomy in the countryside.

The journey to the estate of Jakub's paternal grandparents - the site of Záhrada [The Garden] - though first motivated pragmatically (Jakub intends to revitalise the property to make a better sale to get cash to buy something in the city) soon transforms into a journey of discovery of the lost paradise and genuine values of his ancestors. It is not only the privilege of being exposed to natural phenomena through a naked eye (Jakub waking up with a flea walking on his eyelid), but also to the space of magic and healing properties of a young girl who in many ways reminds us of the tradition of desexualised idylls centred upon Virgin Mary.

Reflecting on this Šulík's film, Czech philosopher Vlastimil Zuska distinguishes at least three fundamental aspects of the chronotope of the idyll, as defined by Mikhail

\footnotetext{
${ }^{9}$ FOUCAULT, M. Of Other Spaces: Utopias and Heterotopias, p. 4.

${ }^{10}$ Ibid., p. 6.
} 
Bakhtin: ${ }^{11}$ this garden is an enclosed and self-sustaining space, governed by cyclical time and offering deep exposure to a fruitful and balancing cycle of seasons, even though in no material way connected to the outer world; action is reduced to the few basic activities of life: love, work, eating, drinking - while any sexuality remains subdued; and, above all, the space of human life overlaps with the spaces of natural processes (the protagonist's bedroom is inhabited by birds, and the garden is not only home to him but also to an ant hill). ${ }^{12}$

The space of Záhrada [The Garden], thus defined, comes to resemble the Garden of Paradise, inhabited by a "Miraculous Virgin"13 while simultaneously drawing upon Slovak literary and filmic tradition. ${ }^{14}$ The chronotope of the idyll, however, in no way contradicts but rather feeds on or cohabits with our viewing of Záhrada [The Garden] as a heterotopia of crisis, namely in the light of its transformative quality for the main character, his father, and the "Miraculous Virgin" herself. Foucault singles out the garden as a prime example of heterotopia, while at the same time emphasising and pointing out the heterochronic aspect of certain heterotopias. ${ }^{15}$ Šulík's Záhrada [The Garden], we could argue, evinces multiple moments of heterochrony. These are exemplified not only by the main character shifting from the time of modern urban space to the cosmic time of the garden, but also by presences coming from different times into the main character's mental landscape. For the main character, who is a somewhat burned out teacher, a whole new dimension of the garden opens up when he discovers his grandfather's diaries. The diaries, set down in Leonardian mirror writing, unfold horizons of pre-communist knowledge which carry Jakub back to the traditions of the Slovak Enlightenment. Hence, the film develops a sophisticated web of intertextual references, some of which are key to the national tradition. The film's individual chapters are titled using archaic Slovak from the time of the Enlightenment. In particular, the titles resemble Juraj Fándly's Pil'ní domajší a polní hospodár ([The Industrious Domestic and Field Farmer] $1792-1800),{ }^{16}$ in conjunction with certain variations stemming from Jozef Ignác Bajza's bildungsroman Reného mlád'enca príhodi a skúsenosti ([The Adventures and Experience of the Young Man René], 1784 - 1785). ${ }^{17}$

The garden feels like a nearly perfect asylum. Yet, it is not an asylum but rather, a heterotopic space of self-transformation which, according to Foucault, "presuppose[s] a system of opening and closing that both isolates them [heteroto-

${ }^{11}$ BAKHTIN, M. Forms of Time and of the Chronotope in the Novel. In The Dialogic Imagination. Austin : Univ. Texas Press, 1981, pp. $84-258$.

12 ZUSKA, V. Topos zahrady v „Záhradě“ a jeho časo-znakové implikace. In BRÁZDA, M. (ed.). Svet v pohyblivých obrazoch Martina Šulíka. Bratislava : Slovenský filmový ústav, 2000, pp. 124 - 129.

${ }^{13}$ Ibid., p. 123.

${ }^{14}$ Panna zázračnica [Miraculous Virgin] is a novel by Dominik Tatarka drawing upon poetics of the Slovak Surrealism, turned into a film by Štefan Uher (lead representative of the Slovak New Wave) released in 1966.

${ }^{15}$ FOUCAULT, M. Of Other Spaces: Utopias and Heterotopias, p. 6.

${ }^{16}$ Much alike Fándly's book, grandfather's diaries comprise not only advice for farmers but also a treatise on planets; at the same time, the ant hill featured in the film directly corresponds with industrious ants reflected upon in the Fándly's work.

${ }^{17}$ GINDL-TATÁROVÁ, Z. Záhrada = The Garden. In HAMES, P. (ed.). The Cinema of Central Europe. London - New York : Wallflower Press, 2004, p. 247. 
pias] and makes them penetrable. "18 The garden's insularity quickly turns out to be fragile, its borders violable. The solitary garden idyll is regularly violated, or rather challenged, by different visitors and visitations: Jakub's father and lover come, as well as a tomcat named Baruch - an apparent reference to the philosopher Spinoza. The garden also hosts other "passers-by", named after major philosophers, who stop there to share a few remarkable sentences. As a result, the space of the garden, originally defined as a space of self-searching, becomes inhabited by references to a number of the founding fathers of Western civilisation: Jean-Jacques Rousseau, St. Benedict, Ludwig Wittgenstein.

These visitors make their "trespassing" as fantastic as it may be, a well-announced event by a kind of jolt to the frontiers of the garden's idyll physical walls (Rousseau bulldoses a part of the garden wall with his Peugeot oldtimer). This jolt manifests in various guises but is always of a grotesque or absurd nature. Consequently, the solitary self-enclosed idyll as a form of singular space opens up and transforms into a field of openness which ultimately leads to Jakub's reconciliation with his father, bringing the crisis heterotopia to a cathartic climax.

\section{The Transformative Power of the Multi-layered City}

However unique was the vision of Záhrada [The Garden], its version of transformative heterotopia was by far not the only one that emerged in Slovak cinema at that time. Just one year before the release of Šulík's film, Miroslav Šindelka and Štefan Semjan, Šulík's generational peers, each had released a film that, unlike Šulík's Záhra$d a$ [The Garden], developed spaces of transformative heterotopia in the urban environment.

Šindelka's Vášnióy bozk [A Passionate Kiss] 1994, offers a space that is vertically stratified. The plot is set in a mining town, one of the most important mining towns of medieval Europe, Banská Štiavnica, within which the film manages to address several levels of historical and human experience (starting from the depths of centuries - old mining tunnels.

The plot focuses on a married couple on their way from the ancient town to the husband's future bright career in the capital. At the same time, we learn the couple left behind not only their regional experience, but also their disabled son. At crossroads in their lives, which they both increasingly perceive as a crisis in their relationship (interestingly, they never use other spouse's name), the couple appears to be psychically affected as they wait for a decision about the husband's next career position. They both have their secrets: the husband uses erotic services in the city's underground spaces, while the wife comes to accept an invitation from an old Jewish gentleman to visit his apartment, which is imbued with the past and where he reveals his conviction she is a re-embodiment of his deceased wife. Much of the film's action can also be perceived as a sequence of the woman's dream. As a result, the film acquires a somewhat surreal air. The town and the main characters, as presented in the film, appear as if taken out or even isolated from the processes of everyday life, which suggests the same heterotopic quality as in Šulík's film.

${ }^{18}$ FOUCAULT, M. Of Other Spaces: Utopias and Heterotopias, p. 7. 
What's more, the multi-layered stratification of spaces greatly corresponds with Foucault's third principle of heterotopia: "the heterotopia is capable of juxtaposing in a single real place several spaces, several sites that are in themselves incompatible. ${ }^{\prime 19}$ Foucault even suggests the theatre or the movie house as typical examples of heterotopia. It is the local movie house, with its fantastic functionalist decor, that plays a pivotal role in this film. Initially, the husband, elegantly dressed, tries luring his wife to a film show for them to forget about the growing disagreement and reconcile. However, they never manage to enter the theatre together. Later, it is right in front of a huge sign reading "Kino" that their final "passionate kiss" will take place, after which the woman abandons her husband for good. The setting of a mysterious and heterotopic town can be viewed both in opposition, and in parallel, to the utopian space of cinema. The film is rich in heterotopic juxtapositions: the graphic imagery of the husband visiting sites of erotic services vs. the romantic "passionate kiss" resembling that of Gone with the Wind (dir. Victor Fleming, 1939). The utopian space of cinematic romance is juxtaposed with the woman's inability to find satisfaction in the marriage.

The heterotopic quality of the film town is even more distinctly highlighted by its multi-layered vertical stratification. The growing alienation of the married couple is made manifest in their divergent gravities toward different strata of the heterotopic space: the husband is a frequent visitor of long-abandoned underground tunnels now turned into an erotic night-club, with all kinds of illegal business thriving - characteristic of the economic transformation of the early capitalist period. Meanwhile, the wife is drawn to a semi-abandoned mysterious building and, further up, to the attic apartment of the elderly Jewish man who tells her the story of his life-long love.

The film can be said to develop a 'heterochronous connection' since the elderly man believes the female character to be an embodiment of his own wife (who he believes died about half a century earlier). The film shows us some of the grounds for his belief: the sizeable painting of Esther, his wife, bears a striking resemblance to the female character. Moreover, the elderly man points to the forces of magnetism, embodied in the character of "magnetic Viktor," who in his own words, brought the young attractive female into the unlikely encounter with him. The gentleman's claim is substantiated by a number of material events and phenomena that govern the attic apartment and the mysterious historic building. It is the force of declared "magnetism" that pulls them both out of the historical time outside as the woman is taken in by the hypnotic quality of heterochronous narrative.

Here we also learn that the elderly man apparently lost his wife during World War II as the Jewish couple was trying to flee the country after they were forced to leave their child behind. The encounter with heterochronous time and heterotopic space in the attic catalyses a transformation in the female character that leads her to recognise that her top priority is to stay faithful to her role as mother - even if it means disassociation from her husband. This awareness is also greatly enhanced by her "recalling" in a hypnotic dream of the events surrounding the death by drowning of her apparent Jewish alter-ego Esther. This dream reveals to her that Esther was

19 Ibid. 
not shot dead, even though her husband believes this to be true, but was possibly able to survive by swimming out of the sinking car. This alternative history suggests that Esther secretly returned to her child despite her husband's decision to flee the country. The heroine takes the dream as an instructional one for her own life, as she consequently decides not to follow her husband to the capital, but, instead, to reunite with her abandoned son and stay with him in a kind of pastoral idyll in the countryside, "far from the madding crowd" of early capitalist urban turmoil. The film's ending can be seen as having a cultural affinity to the rural idyll of Šulík's Záhrada [The Garden], released just one year later.

The two contrasting heterotopic spaces in Vášnivý bozk [A Passionate Kiss], very much like the space of Záhrada [The Garden], play out comparable functions of crisis heterotopias: not only do they serve as a temporary recourse, but they also catalyse the main characters to rediscover their genuine selves. At the same time, Šindelka's film introduces the concept of urban space as a cluster of different cultural patterns and traditions, as well as a layering of the legal and the illegal, the apparent and the hidden - much like another film of the period - Štefan Semjan's debut Na krásnom modrom Dunaji [On the Beautiful Blue Danube] 1994, which was to develop a cult following.

As the film's title suggests, the film is set in Slovakia's capital, Bratislava, often nicknamed "the Beauty on the Danube." At the same time, the title suggests a somewhat fluid, floating environment evocative of the early years of "wild capitalism", when ethics and identities became highly fluid. In a series of loosely connected, sometimes even disjointed episodes, the film presents a story of three friends, bohemians, "heroes of the new times" starring three leading personalities of Slovak cinema who act using their own civic names. The three characters embark on a "pulp crime" adventure - they pretend to steal an Andy Warhol painting from the Slovak National Gallery in order to get paid for distracting the police from the real thief. Hired by the mysterious Mr. Lévy, a mafia boss of Russian-Jewish origin, who is behind the misappropriation of the true original, they keep on waiting and searching for their pay with the hopes of making it big in "the free world." During their anabasis, awaiting their means to "conquer the world", they indulge in hedonistic activities such as frequent visits to the airport to watch planes taking off "to the world", combined with their drug induced "take-offs," explicit sex adventures, driving around the city to the tunes of The Lounge Lizards' Voice of Chunk.

The fluid urban environment offers a whole range of contexts or situations of heterotopic quality. The first remarkable example of heterotopia can be seen in the early minutes of the film when the film trio seek and find refuge, hunted down by police, inside a U.F.O.-shaped construction of a large mirrored café, towering over the Bridge of the Slovak National Uprising. The space of the café is a vista hovering high up above the river, accessible only by an elevator and subject to a special fee. As quoted above, according to Foucault, "heterotopias always presuppose a system of opening and closing that both isolates them and makes them penetrable." ${ }^{20}$ The ambivalent penetrability of this café is made apparent when our three main characters block the elevator with a youthful joke of sticking chewing gum onto the elevator's door sensor. They not only privatise the café space for themselves but also make

\footnotetext{
${ }^{20}$ Ibid., p. 7.
} 
it impossible for the police to get to them. As patrol helicopters bring the police high up, they - and we - observe our heroes having fun inside, making playful faces, safely inside their heterotopia.

On a broader plane, with their trajectory being shaped simultaneously by their attempts to escape the police and reach Mr. Lévy, who leaves them a series of indications on how to reach him and their booty, all of the city becomes a kind of crisis heterotopia within the open world freshly after the lifting of the iron curtain.

The film narrative brings our main characters into confrontation with some of the capital's key cultural and historical landmarks, such as monuments, memorials, lieux de mémoire, or places of national cultural significance. These include the Slovak National Gallery, a vista café towering over the Bridge of the Slovak National Uprising, and Slavín National Monument - a cemetery dedicated to the Soviet Army soldiers killed while liberating Bratislava. These topoi sacred to the national history and culture - all of which belong to the most remarkable architectural artefacts of the socialist period - become the site of the characters' de-sacralising, iconoclastic interventions that strip them of their cultural aura.

The film presents the capital city as a patchwork of loosely juxtaposed spaces, or a fluid matrix of incongruent heterotopias connected by the protagonists. Their incessant mobility makes for a highly fluid experience and a film that shifts between the different spaces of their crisis heterotopia.

The fact that the protagonists mostly move in public places is not contradictory to our interpretation and identification of heterotopias in the film. The characters' playful behaviour regularly transforms public space into a private domain. According to Foucault, heterotopias presuppose a certain sense of exclusiveness: "In general, the heterotopic site is not freely accessible like a public place." ${ }^{21}$

Along with sites of national cultural significance, our heroes venture to places that had been abandoned or neglected by the socialist economy and not yet reconstructed under the capitalist system - sites which themselves are a form of heterotopia. One such site is the functionalist swimming pool not far from the National Parliament.

In the end, the whole city of Bratislava - "the Beauty on the Danube" - is transformed by their imaginative frolics and wild behaviour, it even resembles a "ship of fools" sailing into the unknown in the years of early capitalist transformation. As Foucault wrote in the conclusion to Of Other Spaces: "The ship is the heterotopia par excellence. In civilizations without boats, dreams dry up, espionage takes the place of adventure, and the police take the place of pirates." 22

At the time of the film's creation, the city of Bratislava had just shaken off the iron curtain, which ran just outside the city limits, and was quickly re-establishing itself as a crossroads of cultural influence. It feels quite natural, then, that the film presents the city space as a cluster of different heterotopias of cultural signifiers. The film presents Bratislava as exposed to Russian influences (though with some mafia connotations), but also, even more importantly, American artistic influences (Warhol paintings, The Lounge Lizards' music, American iconography of main heroes' garments and, last but not least, overt or implied references to independent or popular American film) as well as liberal ideology of material improvement.

\footnotetext{
${ }^{21}$ Ibid.

${ }^{22}$ Ibid., p. 9.
} 
The private sanctuary the three main characters jointly inhabit comes to an end when the trio parts ways. Maroš flees abroad with all of the booty they eventually get from Mr. Lévy, Ady gets married - putting the utopia of love above other priorities, and Duro decides to take it easy, now free to return to his wife and little son. The film finale only confirms the catalysing quality of the crisis heterotopia (materialised in their shared experience and the optics of the city it provides) that has a transformative effect on all three characters.

\section{Conclusion}

Given the historical context, the heterotopic spaces of Záhrada [The Garden], Vášnivý bozk [A Passionate Kiss], and Na krásnom modrom Dunaji [On the Beautiful Blue Danube] can also be understood as self-reflexive messages by and for the professional community of filmmakers. In the light of the rich range of its intra- and inter-textual contexts, Sulík's Záhrada [The Garden] can also be understood as a metaphor for the Slovak intelligentsia's quest for cultivation in the rogue years of dramatic economic change that left many stranded and disillusioned, having lost much of their Velvet Revolution ideals. Vášnioý bozk [A Passionate Kiss] offers a multi-layered urban heterotopia amidst a rural idyll, which, as experienced by the main female character, helps her to re-centre her identity around her maternal instinct and involves an overt rejection of cinematic utopia. Finally, Na krásnom modrom Dunaji [On the Beautiful Blue Danube] develops the cinematic space of the Slovak capital as a cluster of multiple heterotopias that, collectively, conceive of urban space as the voluntary internment, or rather a trial for the "heroes of the new times" undergoing transformation thanks to their own privately developed heterotopias of crisis that are seen differently or even overlooked by the police and the mafia. All three films make more or less explicit reference to the then-prevalent crisis of the national cinema production. In each of them, the main characters both undergo a crisis and can be seen as their creators' alter-ego. The period of crisis gave rise to an elaborate examination of the concept of 'heterotopia', while at the same time encouraged the transformation and re-invention of both the characters and the cultural environment per se.

The study is an output of the grant project VEGA 2/0120/18 Institutional, Productional and Co-productional Relations Between Public-Service Television and Film Production after 1989.

Translated by Martin Solotruk

\section{LITERATURE}

BAKHTIN, Mikhail M. Forms of Time and of the Chronotope in the Novel. In The Dialogic Imagination. Austin : Univ. Texas Press, 1981. 434 p. ISBN 0-292-71527-7.

FOUCAULT, Michel. Of Other Spaces: Utopias and Heterotopias. [online]. [cit. 16 May 2020]. 9 p. Available at: http://web.mit.edu/allanmc/www/foucault1.pdf.

GINDL-TATÁROVÁ, Zuzana. Záhrada = The Garden. In HAMES, Peter (Ed.). The Cinema of Central Europe. London - New York: Wallflower Press, 2004, pp. 245 - 253. ISBN 9781904764205.

MACEK, Václav. 1297254000 Sk. In Kino-Ikon, 2010, Vol. 14, Issue 1, pp. 125 - 154. ISSN 13351893. 
MISTRÍKOVÁ, Zuzana - ZMEČEK, Andrej (eds.). Mediálna ročenka - Slovensko 1990 - 2000. Bratislava : Mediálny inštitút, 2001. [online]. [cit. 16 January 2019]. Available at: http://www. mi.sk/medialna\%20rocenka/173/001.html.

ŠMATLÁK, Martin. Hladanie vlastnej cesty. In Kino-Ikon, 2008, Vol. 12, Issue 1, pp. 135 - 147. ISSN 1335-1893.

ZUSKA, Vlastimil. Topos zahrady v „Záhradě“ a jeho časo-znakové implikace. In BRÁZDA, Marián (ed.). Svet v pohyblivých obrazoch Martina Šulíka. Bratislava : Slovenský filmový ústav, 2000, pp. $124-129$. ISBN 8085187191.

Jana Dudková

Ústav divadelnej a filmovej vedy CVU SAV

Dúbravská cesta 9

84101 Bratislava

Slovakia

e-mail: janadudkova@gmail.com 